\title{
PENDAMPINGAN BUDIDAYA UBI KAYU PADA KELOMPOK TANI MAJU JAYA DI NAGARI DURIAN GADANG
}

\author{
Husnarti*1, Sevindrajuta $^{2}$, Fitri Ekawati ${ }^{3}$ \\ ${ }^{12}$ Fakultas Pertanian, Universitas Muhammadiyah, Payakumbuh. \\ ${ }^{3}$ Fakultas Pertanian, Universitas Andalas, Padang \\ email : atigituloh_2006@yahoo.com
}

\begin{abstract}
Cassava is one of the most reliable agricultural commodities in Nagari Durian Gadang because cassava is the main raw material for cassava crackers agroindustry which is not only in Nagari Durian Gadang but also in other villages in Akabiluru District, Lima Puluh Kota District. The supply of cassava certainly greatly affects the sustainability of the cassava cracker agro-industry production. Maju Jaya farmer group as one of the cassava suppliers experienced problems in the cultivation of cassava, namely the existence of tuber rot disease that attacks their cassava plants. So that the productivity of cassava decreases. The purpose of this service is to increase farmers 'knowledge about pest control of cassava, especially root rot. This dedication can increase farmers' knowledge in suppressing cassava pests and diseases so that cassava production can be increased again
\end{abstract}

Kata Kunci: Cassava Cultivation, Trichoderma Fungi

\begin{abstract}
Abstrak
Ubi kayu merupakan salah satu komoditi pertanian yang sangat diandalkan di Nagari Durian Gadang karena ubi kayu merupakan bahan baku utama bagi agroindustri kerupuk ubi kayu yang tidak hanya ada di Nagari Durian Gadang tapi juga di nagari lain yang ada di Kecamatan Akabiluru Kabupaten Lima Puluh Kota. Pasokan ubi kayu tentunya sangat mempengaruhi keberlangsungan produksi agroindustri kerupuk ubi kayu tersebut. Kelompok tani Maju Jaya sebagai salah satu pemasok ubi kayu mengalami kendala dalam budidaya ubi kayu, yaitu adanya penyakit busuk umbi yang menyerang tanaman ubi kayu mereka. Sehingga produktivitas ubi kayu menurun. Tujuan pengabdian ini adalah peningkatan pengetahuan petani tentang pengendalian hama penyakit ubi kayu khususnya busuk umbi. Pengabdian ini dapat meningkatkan pengetahuan petani dalam menekan hama dan penyakit ubi kayu sehingga produksi ubi kayu dapat ditingkatkan kembali.
\end{abstract}

Kata Kunci: budidaya ubi kayu, jamur Trichoderma

\section{PENDAHULUAN}

Usaha Tani ubi kayu dan pengolahan kerupuk ubi kayu merupakan salah satu mata pencarian utama bagi masyarakat Nagari Durian Gadang. Keberadaan agroindustri kerupuk ubi kayu ini sangat mempengaruhi kesejahteraan masyarakat Durian Gadang seperti petani ubi kayu, pengolah, tenaga kerja, pedagang pengumpul.

Perkembangan dan keberlanjutan agroindustri kerupuk ubi kayu sangat dipengaruhi oleh pasokan ubi kayu sebagai bahan baku utama. Ubi kayu yang bersifat musiman karena harus menunggu selama 812 bulan untuk bisa dipanen menyebabkan kondisi pasokan tidak stabil. Terdapat kondisi dimana pasokan ubi kayu lancar dan ada kondisi dimana pasokan ubi kayu tidak lancar dan juga terdapat kondisi dimana pasokan ubi kayu melebihi kebutuhan pengolah. Menurut Husnarti (2015), disaat kondisi pasokan ubi kayu tidak lancar sebanyak 55\% pengolah pernah berhenti untuk sementara memproduksi 
kerupuk karena tidak tersedianya ubi kayu sebagai bahan baku utama. Kalaupun ada yang menawarkan ubi kayu, namun harganya lebih tinggi dari harga ubi kayu yang biasa pengolah beli. Karena takut tidak memperoleh keuntungan pengolah lebih memilih untuk sementara berhenti memproduksi kerupuk sampai memperoleh ubi kayu yang harganya sesuai dengan kemampuan pengolah. Ada juga pengolah yang memilih untuk mengurangi jumlah produksi dari pada berhenti memproduksi. Pengolah tersebut mengurangi jumlah produksinya setiap harinya hingga mencapai $50 \%$ lebih sedikit dari biasanya dengan alasan ingin menghemat ubi kayu sehingga produksi bisa terus berjalan walau dengan kuantitas yang dibatasi.

Kekurangan pasokan ubi kayu juga dipengaruhi oleh dua faktor yang pertama; menurunya produksi ubi kayu yang disebabkan oleh serangan hama penyakit dan kedua; mulai beralihnya petani ke komoditi lain seperti talas karena serangan hama penyakit pada tanaman ubi kayu. Menurut Husnarti (2017), petani mulai menanam talas dengan alasan lahan mereka tidak bisa ditanami ubi kayu karena diserang penyakit busuk umbi disaat usia muda dan penyakit lainnya. Sedangkan komoditi talas masih belum dibutuhkan dalam jumlah yang banyak seperti halnya kebutuhan terhadap ubi kayu karena di Nagari Durian Gadang dan sekitar belum banyak pengolah kerupuk talas.

Menurut Rahayu (2017), penyakit pada tanaman ubi kayu dengan gejala kerusakan daun yaitu daun menjadi kekuningan, tanaman layu, dan gugur daun premature. Penyebabnya karena infeksi mikroorganisme di bagian organ tanaman dibawah tanah yaitu perakaran dan umbi. Gejala penyakit sangat khas yaitu pada bagian atas dan bagian bawah tetap hijau, tetapi daun bagian umbi pada akar serta tumbuh perakaran kedua yang tidak berumbi. Pada hambatan populasi ubi kayu, pertumbuhan tanaman tidak merata sehingga mirip fenomena hamparan yang bergelombang. Fusarium adalah pathogen utama yang menyebabkan kerusakan umbi pada ubi kayu dengan tingkat kerusakan mencapai $30 \%$. Serangan penyakit terjadi sejak awal pembentukan umbi hingga masa panen pada umur 6 bulan hingga 12 bulan. Menurut Rahayu dan Saleh (2013), hasil penelitian skala rumah kaca menyebutkan bahwa inolukan hayati berupa mikroba seperti jamur antagonis Trichoderma prospeknya cukup baik untuk mengendalikan penyakit busuk akar/umbi.

Kelompok tani maju jaya merupakan salah satu kelompok tani di Nagari Durian Gadang yang mayoritas anggotanya merupakan petani ubi kayu. Untuk itu perlu kiranya dilakukan pelatihan dan pendampingan tentang budidaya ubi kayu dengan menggunakan jamur Trichoderma.

\section{METODE PENGABDIAN}

\section{Kerangka Pemecahan masalah}

Dalam upaya meningkatkan pengetahuan petani tentang penggunaan jamur Trichoderma dalam budidaya ubi kayu untuk menekan penyakit busuk, meningkatkan pengetahuan petani dalam membuat biang jamur Trichoderma meningkatkan pemahaman tentang manajemen rantai pasok dilakukan praktek langsung pembudidayaan ubi kayu dengan menggunakan jamur Trichoderma sekaligus pembuatan biangnya.

\section{Realisasi Pemecahan Masalah}

Praktek budidaya ubi kayu dan pembuatan biang jamur Trichoderma dilakukan langsung di lahan tempat budidaya ubi kayu. Penyampian materi dan penyuluhan dilakukan dengan metode diskusi dan Tanya jawab, kemudian dilanjutkan dengan praktek budidaya ubi kayu dan pembuatan biang jamur Trichoderma.

\section{Metode Pelaksanaan}


a. Berkoordinasi dengan perangkat Nagari Durian Gadang dan Kelompok Tani Maju Jaya untuk teknik pelaksanaan.

b. Melakukan survey pendahuluan terhadap lahan yang akan digunakan dalam budidaya ubi kayu

c. Melakukan penyampaian materi tentang teori-teori budidaya ubi kayu

d. Melaksanakan praktek langsung budidaya ubi kayu dan pembuatan biang jamur Trichoderma.

\section{HASIL DAN PEMBAHASAN}

Program pengabdian kepada masyarakat yang diikuti oleh semua anggota kelompok Tani Maju Jaya di Nagari Durian Gadang Kecamatan Akabiluru Kabupaten Lima Puluh Kota. Dalam program pelatihan yang dilaksanakan diikuti secara antusias oleh peserta. Anggota kelompok tani mendapatkan penjelasan tentang budi daya ubi kayu secara umum dan beberapa penyebab munculnya penyakit busuk umbi beserta cara mengatasinya, peran jamur Trichoderma dalam menekan penyakit busuk umbi,. Selanjutnya dilakukan praktek budidaya ubi kayu dan pembuatan biang jamur Trichoderma. Dalam praktek budidaya lebih ditekankan meminimalisir pupuk kimia untuk menghindari residu yang berlebihan dalam lahan yang digunakan.

Pengetahuan yang diperoleh diharapkan dapat diterapkan sehingga diperlukan monitoring dan pendampingan. Antusiasme anggota kelompok tani Maju Jaya ditunjukkan dengan keputusan kelompok tani untuk mempraktekkan cara budidaya yang dipraktekkan pada lahan yang berbeda. Kelompok Tani Maju Jaya juga menyampaikan harapan mereka untuk mendapatkan penyuluhan selanjutnya berkaitan dengan pertanian organic serta study banding.

Hal ini menunjukkan bahwa kelompok Tani Maju Jaya merupakan kader yang potensial untuk memberikan pengaruh perubahan bagi kelompok tani lain khususnya dan masyarakat umumnya.
Sehingga diperlukan upaya komunikasi yang lebih intensif untuk dapat berlangsungnya program-program pendampingan dan pemberdayaan masyarakat.

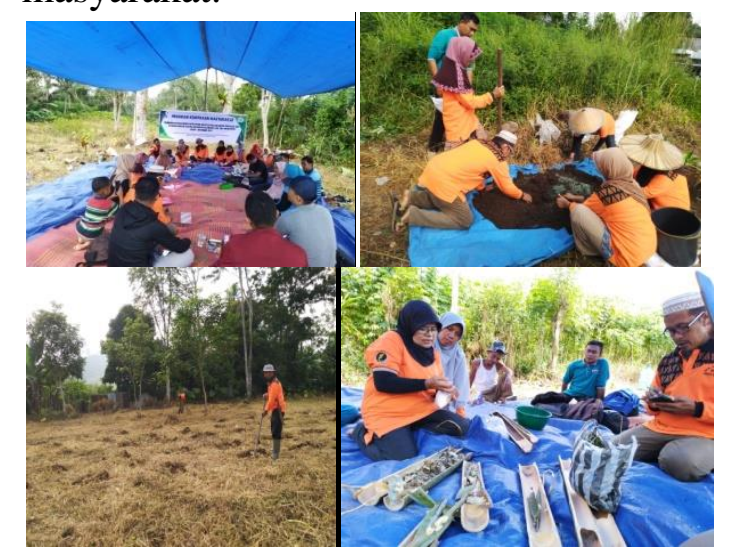

Gambar 1. kegiatan Materi dan Praktek

\section{SIMPULAN}

Penyuluhan dan pelatihan yang dilakukan pada Kelompok Tani Maju Jaya di Nagari Durian Gadang dapat meningkatkan pengetahuan dan pemahaman anggota tentang budidaya ubi kayu dan penanggulangan busuk umbi pada tanaman ubi kayu, pembuatan biang Jamur Trichoderma.

\section{UCAPAN TERIMA KASIH}

Program pengabdian kepada masyarakat ini merupakan bagian dari kegiatan Hibah PKM tahun 2019. Untuk itu ucapan terimakasi kami sampaikan kepada:

a. Direktorat Riset dan Pengabdian Kepada Masyarakat (DRPM)

b. Direktorat Jenderal Penguatan Riset dan Pengembangan

c. Kementerian Riset, Teknologi, Pendidikan Tinggi (Kemenristekdikti) Republik Indonesia

d. Lembaga Penelitian dan Pengabdian Kepada Masyarakat (LPPM) Universitas Muhammadiyah Sumatera Barat.

e. Nagari Durian Gadang

f. Kelompok Tani Maju Jaya

\section{DAFTAR PUSTAKA}


[1] Husnarti. 2015. Analisis Aliran Aktivitas dan Lembaga-Lembaga Yang Terlibat Dalam Rantai Pasokan Kerupuk Ubi Kayu di Kabupaten Lima Puluh Kota. Jurnal Menara Ilmu Vol IX Jilid I No 56 Maret 2015

[2] Husnarti. 2017. Analisis Usahatani Talas Kimpul di Nagari Durian Gadang Kec Akabiluru Kab Lima Puluh Kota. Jurnal Pertanian UMSB Vol 1 no 2 Desember 2017

[3] Rahayu Mudji. 2017. Evaluasi Ketahanan Klon Harapan Ubi Kayu (Manihot Esculanta Cranz) Terhadap Penyakit Layu dan Busuk Umbi. Primordia Volume 13 Nomor 1 April 2017

[4] Rahayu Mudji dan Nasir Saleh. 2013. Penyakit "leles" pada tanaman ubi kayu bioekologi dan cara pengendaliannya. Buletin Palawija no 26 Tahun 2013. 